\title{
Ethics in Context: The Thessalonians and their neighbours
}

\begin{abstract}
Author:
Abraham J. Malherbe ${ }^{1,2}$

Affiliations:

${ }^{1}$ New Testament Studies, Yale

University, United States

${ }^{2}$ Department of New

Testament Studies, University

of Pretoria, South Africa

Note:

Prof. Abraham J. Malherbe

is a research associate

of Prof. Dr Kobus Kok at

the Department of New

Testament Studies, University of Pretoria, South Africa, in

the research field of Mission and Ethics.

\section{Correspondence:}

Abraham Malherbe

Email:

abraham.malherbe@yale.edu

Postal address:

71 Spring Garden Street,

Hamden, CT, USA 06517 -

1913

Dates:

Received: 09 Jan. 2012

Accepted: 22 Feb. 2012

Published: 29 June 2012

How to cite this article:

Malherbe, A.J., 2012,

'Ethics in Context: The

Thessalonians and their neighbours', HTS Teologiese

Studies/Theological Studies

68(1), Art. \#1214, 10 pages.

http://dx.doi.org/10.4102/

hts.v68i1.1214
\end{abstract}

C 2012. The Authors.

Licensee: AOSIS

OpenJournals. This work

is licensed under the

Creative Commons

Attribution License.
First Thessalonians was written within a few months, following the conversion of Paul's Greek readers, and reflects how his ethical teaching was part of his proclamation. Paul's preaching of the gospel, intimately connected with the kind of person he was, brought about a close personal relationship between him and his converts. Whilst he stood as a moral model for them, he nevertheless spoke for God, and thus, his ethical instruction was grounded theologically. His converts would have understood how moral dicta, with which they were familiar, were derived from philosophy, but not from religion, as Jews and Christians held. In the overtly paraenetic sections of the letter (ch. 4 and 5), Paul was at great pains to underline this connection, which was the main point he was making.

\section{Introduction}

First Thessalonians lends itself to what I understand the interest of this conference to be, for three reasons: firstly, the letter was written soon after Paul's missionary activity amongst the recipients of the letter, and reflects that activity more clearly than is revealed in any of his other letters; secondly, the letter exhibits a pronounced interest in the recent converts' relationship to the environment which had formed them before they became Christians, thus, it exhibits interest in their neighbours and their thinking; thirdly, the letter is paraenetic in style and is largely so in content, and it is thus concerned with the moral formation of Paul's converts. These elements will be treated in the course of my article ${ }^{1}$.

\section{The Letter}

\section{The autobiographical and historical narrative}

We begin with a brief comment on the circumstances of the writing of the letter. The letter consists of five chapters, the first three of which are autobiographical and historical, and the last two contain practical advice, or paraenesis. Without the context of the historical narrative of chapters $1-3$, which essentially describe Paul's founding of this church, we will not be able to appreciate the missionary dimension of Paul's ethical instruction in the letter.

Paul arrived in Thessalonica in the summer of the year AD 49. He left this place two or three months later, having spent only this short period of time founding the church. Finding himself in Athens, he sent Timothy, who had come from Macedonia, back to Thessalonica. He moved on to Corinth in early AD 50, where Timothy again caught up with him, bringing news about the church in Thessalonica. He wrote 1 Thessalonians soon after Timothy's arrival. He thus wrote the letter six to eight months after he first set foot in Thessalonica and about four months after he had left the city (Malherbe 2000:71-74).

The letter confirms this reconstruction. It reflects a young church, and is positive and intent on strengthening the recent converts. Paul uses passionate language, dripping with sentiment and pathos, especially when speaking of his desire to return to them. He recalls his efforts to overcome his enforced separation from them when Satan hindered him, leaving him a desolated orphan until Timothy returned with news that made him overflow with thanks and joy.

Paul writes in this way, not to defend himself for any reason, as is sometimes thought, but as I have argued in my commentary on the letter, to lay a philophronetic foundation for the practical advice he would give in chapters 4 and 5. He describes a relationship that he claims was extraordinarily close and personal from the first time he came in contact with them. It is only after that bond has been strengthened, by calling their short mutual history to mind, that he sets about to fill what was lacking in their faith (3:10), which turns out to be guidance on some aspects of their moral life. The function of this narrative, then, is not apologetic but has already extended to being paraenetic.

1.This article is heavily dependent on my commentary, The letters to the Thessalonians (Malherbe 2000:71-78). 


\section{The occasion for writing 1 Thessalonians}

I wish to focus on the two brackets to this historical narrative, and turn first to its end, 3:5-7, where Paul recounts the circumstances that led to the writing of this letter. At the end of his historical narrative, Paul expresses himself in contemporary conventional form when he plaintively remarks on the mutual desire to see each other face to face. This was an epistolographic feature of so-called 'letters of friendship.' More significant for our immediate purpose is Timothy's good news that Paul's recent converts 'always have a good memory of him' (3:6), which amounts to an expression of confidence that they still looked to him for guidance (3:6-7) (Malherbe 2000:206-208). Paul here uses a convention from the contemporary moral hortatory tradition, which described the ideal relationship between a recent convert to philosophy and his teacher, who had moved on after bringing his recent convert to conversion. An example is found in Lucian, where the convert, in this case a certain Nigrinus, is speaking:

Then, too, I take pleasure in calling his words to mind frequently, and have already made it a regular exercise: even if nobody happens to be at hand, I repeat them to myself two or three times just the same. I am in the same case with lovers. In the absence of the objects of their fancy they think over their actions and their words, and by dallying with these beguile their lovesickness into the belief that they have their sweethearts near; in fact, sometimes they even imagine that they are chatting with them and are pleased with what they formerly heard as if they were just being said, and by applying their minds to the memory of the past give themselves no time to be annoyed by the present. So I too, in the absence of my mistress Philosophy, get no little comfort out of gathering the words that I then heard and turning them over to myself. In short, I fix my gaze on that man as if he were a lighthouse and I were adrift at sea in the dead of night, fancying him by me whenever I do anything and always hearing him repeat his former words. Sometimes, especially when I put pressure on my soul, his face appears to me and the sound of his voice abides in my ears. Truly, as the comedian says, 'He left a sting implanted in his hearers.' (Nigrinus 6-7 [LCL, transl. A.M. Harmon])

Associated with this theme of remembrance of the teacher, indeed its presupposition is that the teacher had become the model or paradigm for the convert. The teacher could call on others to follow his example because he had attained a moral status that authorised him to make demands. By presenting himself as a model, he demonstrated three things:

- that his moral demands could be achieved

- that he showed in concrete terms what was demanded

- and that he made a commitment to continue acting in the same way.

Paul uses this convention elsewhere. For example, in 1 Corinthians 4:14-21, at the end of the introductory section of the letter, before he gives explicit directions on how to behave in certain circumstances, he claims a special relationship with his readers: he is their spiritual father, having begotten them through his preaching of the gospel to them, not on the basis of his personal attainment of moral superiority. His fatherhood in the gospel allows him to call on his children to become imitators of him. What that means, he says, Timothy his child will remind them of:

I exhort you therefore, brethren, be imitators of me. For this reason I sent to you Timothy my beloved and faithful child in the Lord, who will remind you of my ways in Christ Jesus. (1 Cor 4:16-17)

Paul remains their paradigm in his absence. What is required is that they continue to remember him. Thus, Timothy returns to Paul from the Thessalonians and reports that they 'always have a good memory' of him, they are already doing what he wants the Corinthians to do (cf. 4:1, 10; 5:11).

We turn to the other bracket of the historical narrative. In 1 Thessalonians 1:5-7, he uses the convention in a manner quite different from 1 Corinthians. Here he reminds them of something they already know (vv. 4-5), the circumstances of their conversion:

For our gospel came to you not in word only, but also with power and the Holy Spirit and with a full conviction, fully in conformity with the kind of persons we proved to be amongst you for your sake; so you on your part became imitators of us [in

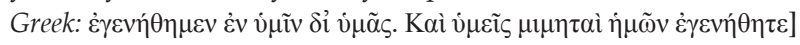
and the Lord by receiving the word in deep distress and with joy inspired by the Holy Spirit, with the result that you [ن $\left.\tilde{\mu}_{\alpha} \varsigma\right]$ became an example to all the believers in Macedonia and Achaia. For from you [àं $\left.{ }^{\prime} \dot{v} \mu \tilde{\omega} v\right]$ the word of the Lord has sounded forth ...

The stress here is on the powerful manner in which the gospel had come to the Thessalonians and brought about their relationship with Paul. Unlike 1 Corinthians 4:15, where it is Paul who, through the agency of the gospel, begets them, thus creating a paternal relationship with his converts, in 1 Thessalonians the stress is otherwise. Here the stress is on the dynamic character of the gospel which brings about the intensely personal relationship between Paul and his converts, expressed in the inelegant but forceful piling up of personal pronouns. What Paul, in chapter 1 , simply calls 'our gospel' (1:5) or 'the word of the Lord' that the Thessalonians in their turn preached (1:8), he repeatedly calls 'the gospel of God' in chapter 2 (vv. 2, 8, 9), which he had been entrusted with (2:4), and which God had emboldened him to speak (2:2). The Thessalonians had received that message from him for what it truly was, not a human word, but the word of God, which was at work in them, the believers. This is explained ( $\gamma \alpha \dot{\alpha} \rho)$ by their, on their part, having become imitators of God's churches in Judea when they suffered (2:13-14).

What is striking about Paul's description in 1:5-7, of how his gospel came to them, is that the gospel was not separated from the kind of person he was. They became imitators of him and the Lord when they accepted the word with much affliction mixed with joy (1:6). The reference here is likely to the self-giving of Christ who, he says in 5:9-10, died for us so that we might not experience God's wrath but be saved by Christ so that we might live with him.

For his part, Paul reminds his readers in 1 Thessalonians 2:7-9 how he had ministered to them (see Malherbe 1970): 
Although we might have made harsh demands on you as apostles of Christ, yet we were gentle in your midst; as a nurse who cares for her own children, so we, having tender affection for you gladly determined to share with you not only the gospel of God but our very selves, because we had come to love you. For you remember brethren, our labour and toil; working night and day in order not to burden any of you we preached the gospel of God to you.

In this self-presentation in chapters 1 and 2, the gospel comports to the kind of person he showed himself to be. In Paul's life the gospel had become transparent. For our immediate interest, what is notable is that Paul's ethical instruction is not separated from his mission preaching, that is, the initial offering of the gospel. The letter provides no evidence for a two-stage activity, the preaching of the kerugma and, subsequently, doctrinal and ethical instruction. The short time that he spent in Thessalonica, founding the church, could hardly have accommodated such periodised activities, nor could the social realities of the mission have included these. Paul was engaged in manual labour, stitching away at his tents whilst preaching in a relatively small space in which manufacture and sales were being conducted (Hock 1980; Malherbe 1987:15-20). He worked out of love for his hearers and to provide them an example of social responsibility $(2: 8 ; 4: 11 ; 2$ Th 3:8-9).

Paul worked at the same time that he preached, and there is no evidence of an earlier scholarly generation's surmise that kerugma was followed by moral catechesis. The imperatives with which he later urges his readers to please God (4:1-2) 'are not derived from an indicative' but 'had been part of Paul's initial preaching in Thessalonica' (Lührmann 1990:249). ${ }^{2}$ The frequently repeated observation that several of Paul's letters comprise two sections, the first dealing with theological matters, which served as the basis for the second, devoted to ethics, does not apply to 1 Thessalonians, whose first part is historical and biographical. The lives of Paul and the Thessalonians were, from the beginning, interwoven by the preaching and receiving of the gospel and teaching on the moral life. Recollecting that earlier association has the philophronetic epistolary function of preparing Paul's readers for the directions in the second part of the letter.

The letter reflects Paul's concern about his converts' faith, his uncertainty about their social relations, whether or not they fully understood the reasons for his moral demands, whether or not they questioned the adequacy of their knowledge, and whether or not they were doing the right things and were making sufficient progress in their new walk. These are perennial problems experienced by recent converts to philosophy or religion, and to these the Thessalonians were no exception (see Malherbe 1987:36-52). It is no wonder, then, that Paul writes that it was out of his own need that he sent Timothy to find out precisely what conditions were like, and,

2.For the indicative or imperative scheme, see R. Bultmann (1924), followed by generations of scholars. Dissatisfaction with it has grown, but attempts to come to terms with it are still being made, for example, by W. Schrage (1968:167-172); Schnelle (2005:546-551). A more creative response, with a sophisticated methodology, is now being undertaken, especially by R. Zimmermann; see methodology, is now being undertaken, especially by R. Zimmermann; see to recent discussion of the issue. most importantly, whether they still looked to him, as they initially had done, as their paradigm of gospel behaviour or not. And it is no wonder that receipt of the good news that they indeed did so, resulted in Paul's effusive expression of joy and gratitude (3:7-10).

\section{A letter to a community}

In the letter that he writes in response to Timothy's good news, Paul focuses on individuals as part of a larger community, which he describes in kinship terms. The letter is

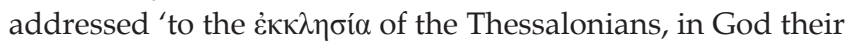
Father and the Lord Jesus Christ.' This is the only time that $\dot{\varepsilon} \kappa \kappa \lambda \eta \sigma i ́ \alpha$ is used of the Thessalonians, and that, in an unusual way, circumscribed as 'in God the Father and the Lord Jesus Christ' (1:1). To be 'in God' is unusual for Paul, and it is likely that 'in' is to be understood instrumentally, as it is in 2:2, 'we were emboldened by غ̇v our God to speak to you.' Read thus, the church is created by God the Father, 'Father' being a designation of God as Creator, as in the creedal formulation in 1 Corinthians 8:6:

But for us there is one God, the Father, from whom are all things, and for whom we exist, and one Lord Jesus Christ, through whom are all things and through whom we exist.

'Father' was used as early as Plato to describe the Creator and is Philo's favourite term for the Creator (Malherbe 2000:99-100). The God who brought the church into existence is then called 'our Father' in two passages which form an inclusio to the historical narrative $(1: 3 ; 3: 11,13)$. So, the community whose origin Paul describes has God the Creator as their Father, before whom they will stand at the Parousia of the Lord Jesus and all his saints.

Despite the kinship language with which the letter is replete, Paul does not replicate a hierarchical structure (Malherbe 1995). He certainly is not the authoritative paterfamilias, as in 1 Corinthians, but rather uses images to describe himself that are affective. Rather than claim the perquisites due an apostle, he claims to have been gentle like a wet nurse, a domestic employee crooning over her charges (2:7). When separated from his recent converts, he felt orphaned, desolate and lonely (2:17). And when he was with them and ministered to them, he did so like a caring father who gave individual attention to them conforming to their dispositions or emotional states, sometimes exhorting, at other times consoling, at others charging them to live in a manner worthy of God, who calls them into his kingdom and glory (2:11-12; cf. 4:1-2).

Paul uses the paternal metaphor to describe his responsible psychagogy, but he is never their father, and he nowhere in the letter calls them his children. He rather addresses or describes his converts as $\alpha \delta \varepsilon \lambda \varphi{ }^{\prime}$ ['brothers'], thirteen times, the highest incidence of the term in all of his letters. The relationship between him and them and amongst themselves is that of siblings. Brothers constitute the church's gatherings (5:25-27). Remarkably, the moral advice in the letter is given in view of the relationship between the brothers: 
- directions on sexual morality forbid transgressing against and wronging one's brother (4:6)

- advice on social responsibility is given within the rubric of brotherly love (4:9-12)

- the consolation after the death of some of them assures them that they will not be separated from each other at the Parousia $(4: 15 ; 5: 10)$

- he enjoins them to comfort each other with these words (4:17-18)

- they should provide the same pastoral care to each other that he has given them, giving attention to each other one on one (5:11), treating each other in ways appropriate to each person's disposition and emotional state as he had practiced (5:12-16; cf. 2:11-12).

The kinship language that Christians used of themselves did not escape the notice of their pagan neighbours. A century after Paul it drew the attention of Lucian of Samosata, who described the speed with which Christians aided people in need, and he cuttingly offered a reason for their behaviour:

Their first lawgiver persuaded them that they are all brothers of one another after they have transgressed once and for all by denying the Greek gods and by worshipping that crucified sophist himself and living under his laws. Therefore they despised all things indiscriminately and consider them common property ... (Lucian, Peregrinus 13 [LCL transl. A.M. Harmon])

Through their conversion they became brothers and sisters and adopted a communal life that distinguished them from the rest of society. Whilst Lucian is merely derisive, Caecilius, another pagan, playing on the much vaunted Christian love for each other, was downright vicious:

They recognize each other by secret marks and signs; hardly have they met when they love each other, throughout the world uniting in the practice of a veritable religion of lusts. Indiscriminately they call each other brother and sister, thus turning even ordinary fornication into incest by the intervention of these hallowed names. Such a pride does this foolish, deranged superstition take in its wickedness. (Minucius Felix, Octavius 9.2 [ACW, transl. G.W. Clarke])

To this slashing accusation, Minucius Felix the Christian apologist replies:

... it is true that we do love one another - a fact that you deploresince we do not know how to hate. Hence it is true that we do call one another brother - a fact which rouses your spleen-because we are men of the one and same God the Father, copartners in faith, coheirs in hope. (Octavius 31.18; cf. Tertullian, Apol. 39)

These pagan criticisms reacted to the self-conscious way in which Christians attributed a special quality to their fellowship by describing themselves as brothers. Caecilius attributed this to pride. Paul pointedly enhanced the quality of the Christian communal life by emphasising the implication of what it meant to be brothers. According to 1 Corinthians, which repeatedly comments on relations with non-Christians, he tells his readers not to associate with a brother who is immoral, but allows social mixing with pagans who act in the same way (5:11-13). The presumption is that the Christian brethren live on a higher ethical level than their pagan neighbours. That also means that Christians are not to drag each other before pagan courts for judgement (6:1-2).

The fraternal relationship came into being with their obedience to the gospel, which according to 1 Corinthians 4:15 was the way Paul begat them. Adolf Harnack (1908), at the beginning of a long chapter in his Mission and Expansion entitled 'The Gospel of Love and Charity', explains the fraternal relationship in this way:

The preaching which laid hold of the outer man, detaching him from the world, and uniting him to his God, was also a preaching of solidarity and brotherliness ... The gospel ... is at bottom both individualistic and socialistic. (pp. 147-149)

One may question what Harnack means by detachment from the world. After all, in 1 Corinthians 5:9-10 Paul cautions that refusing to associate with pagans guilty of the behaviour he condemns in Christians, would mean that they would have to withdraw from the world. What is apt, however, is Harnack's identifications of social as well as individual aspects of conversion.

\section{Summary}

Let me summarise up to this point. Paul begins the letter with a three chapter account of his relationship with his recent converts. The purpose of this narrative is to strengthen the bond between them to form the basis for the moral direction that will follow, in the final two chapters of the letter, which are usually described as paraenetic. The narrative in fact serves a paraenetic function. Paul uses a style adopted from the moral philosophers of his day in this autobiographical narrative, which culminates in an expression of joy that his converts still hold him as the moral example to whom they look for guidance.

But Paul did not develop this relationship with his converts in the way that moralists did. His relationship with his readers was effectuated by the gospel, the word of the Lord, which is not described in terms of its content, but totally according to its power and effect. Paul's gospel was not separated from the kind of person he showed himself to be, and in this section of the letter he establishes his bona fides as their moral instructor.

Paul does not, however, present himself as an authoritative teacher, but as a member of a fellowship of brethren whose Father is the Creator, who brought the church into existence. The conversion of the Thessalonians had both a personal and a social dimension. In a community who called themselves brethren, his moral instruction always had a communal dimension. The behaviour of Christians was later criticised by their opponents because of the exceptionalism they thought inherent in the Christians' description of themselves as brethren. The view of the little group of manual labourers in northern Greece, of themselves as the family of God, had implications for relationships within the fellowship and with society at large. Before examining two texts in which Paul addresses these issues, we need to give attention to the larger intellectual context of moral instruction. 


\section{Philosophy, religion, ethics and mission Philosophy}

Paul uses elements of the Hellenistic moral tradition to describe his ministry in chapter 2 , his psychagogic techniques are derived from that same tradition, and so too, we shall see, is some of the language in which he couches the content of his moral directives in the letter. ${ }^{3}$ It has been demonstrated that Hellenistic Jewish moral instruction did not differ materially from that of the world in which it lived. ${ }^{4}$ Early Christians, too, shared this moral instruction, and the Church Fathers acknowledged the similarity of Christian teaching to that of the moral philosophers. For example, Musonius Rufus, Paul's Stoic contemporary, was widely respected amongst Christians and quoted extensively by Clement of Alexandria, who in fact is our main source for Musonius' lectures; and Seneca, another Stoic contemporary, was referred to by Tertullian as 'frequently our own.' Celsus, the arch opponent of Christians, charged that they shared their system of morals with the philosophers and that there was nothing particularly new or impressive in it, to which Origen agreed. Twentieth century scholarship has demonstrated that New Testament writers, especially those of the Pauline tradition, similarly belong to the philosophical landscape in matters of style, selfdescription and content (Malherbe 1992:267-270). Of course, they differed in significant ways from the philosophers as the latter differed amongst themselves. ${ }^{5}$

The most significant difference was their orientation to the moral life. For the philosopher, morality becomes possible when a person commits himself to live rationally, when he comes to his senses, expressed by Epictetus as turning to himself '̇ாı same word in describing the Thessalonians' conversion, which has moral implications and provides the theological framework of the moral exhortation of the letter:

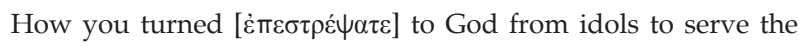
living and true God, and to wait for his son from heaven, whom he raised from the dead, Jesus who delivers us from the wrath to come. (1 Th 1:9-10)

For Epictetus, the moral life is pursued as part of an intellectual enterprise, whereas for Paul, it is a religious service undertaken as one turns to God, the eschatological judge, from whose judgement his son will deliver the convert (cf. 5:9-10). This recollection of their conversion comes after the intensely religious description of Paul's encounter with the Thessalonians, and their ensuing relationship brought about by the gospel of God. Viewed in its cultural context,

3.1 have demonstrated this in my publications. In addition to the works already cited in this article, see Malherbe (1989). For a view privileging Jewish traditions, see Thompson (2011).

4.For Hellenistic Judaism, see Niebuhr (1987:70-72, 2011:251-274); Ameling (2011:241-249).

5.The investigation has progressed to a new level by Engberg-Pedersen (2000 and 2010).

6.For a comparison of conversion as viewed by Paul and the philosophers, see Malherbe (1998); and Nock (1972:63-68) for the pagan understanding of conversion. this religious introduction, to a letter that is essentially ethical instruction, is remarkable for the connection between religion and morality.

\section{Religion}

This connection, viewed as axiomatic by Jews and Christians, was not acknowledged as a matter of course by pagans, those people Paul describes as worshippers of idols, from amongst whom his recent converts came. He has them in mind when he writes the letter. This issue requires further attention.

It has been debated whether or not pagan religion had an essential connection with ethics (Malherbe 1989:61, 2000:241). That the debate has continued for some time proves that such a connection is neither abundantly clear nor obvious. There is much to commend what Edwin Judge has to say on the matter. He begins an article on the notion of religion with a provocative sentence: 'There was no understanding of "religion" in the ancient world of Greece and Rome. No conception as we now hold existed then ...' He points out that our vocabulary of 'religion' does not derive from the Greeks, but that much of it ('religion', 'superstition', 'piety', 'cult', etc.) comes from Latin, and that none of these are concerned with what we call 'religion'. Judge (2010) then describes the distinctiveness of a modern 'religion':

It has (a) an articulate view of the world as a whole, (b) a coherent set of rules for life, and (c) a communal identity that marks it off from other such complexes: 'creed', 'commitment' and 'community', or 'belief', 'behaviour', and 'belonging.' None of these items featured in the so-called 'religion' of GraecoRoman antiquity. One's daily sacrifice did not commit one to any doctrine or pattern of behaviour, nor define any communal life other than the general one. Each of these concerns lay rather with philosophy. (p. 266)

Lately, attention has been drawn to inscriptions from western Asia Minor which reveal a closer connection. Petitioners erected steles on which they confessed to a powerful god that they had sinned and been punished for their wicked deeds. The sins enumerated and repented of, such as perjury, dishonesty in business practices, adultery, and theft, are also condemned by Jews and Christians. I do not yet know enough about these inscriptions despite the excellent guidance I have received from Hans-Josef Klauck (2003), Walter Ameling (2011) and Karl-Wilhelm Niebuhr (2011) to form a responsible judgment about the inscriptions. But eighty years ago A.D. Nock commented on the few of them available to him, that they were from the second century onwards to the fifth, and that the religious elements in them were Lydian and not Greek (Nock 1964:20-22). Since that time, a few earlier ones, one from the middle of the first century AD have come to light, but the bulk of them are from a later period and come from a relatively limited geographical area. Prudence suggests that the inscriptions require closer study before generalizations are ventured.

\section{Judaism and Christianity}

What is more important than such modern interpretations of the evidence, are explicit comments by Jewish and Christian 
writers, particularly the apologetic ones, on the matter of these inscriptions. After all, it is their writings that we seek to understand, as writings whose aim it was to articulate a Jewish or Christian self-understanding to a pagan world.

On the Jewish side, the Epistle of Aristeas may serve as an example. The work describes a banquet scene during which the translation of the Septuagint is celebrated. The Jewish wise men who had done the translation are asked essentially moral philosophical questions, about subjects such as gentleness, justice, courage, piety, to which they respond, always with a reference to God, who is described at the beginning of the scene as 'Almighty God, the Creator of all good things.' The king, who sponsored the translation, compliments them, as, for example, in Epistle of Aristeas 200-201:

When all had expressed approval and signified it by applause, the king said to the philosophers, of whom not a few were present, 'I think the virtue of these men is extraordinary and their understanding very great, for having questions of this sort addressed to them they have given proper replies on the spur of the moment, all of them making God the starting-point of their reasoning.' And the philosopher Menedemus of Eretria said, 'True, Your Majesty; for inasmuch as all things are governed by providence, and these men are right in holding that man is a creature of God, it follows that all power and beauty of discourse have their starting-point from God.

The Jewish apologist neatly combines the claims that Jewish moral teaching is philosophical and located in the teaching of God. There is an inextricable relationship between morality and religion, and therein lies Jewish exceptionalism.

Similar claims are made by the Christian apologists, such as Athenagoras, who claimed that Christian doctrines, taught by God ( $\theta \varepsilon \delta \delta i \delta \alpha \kappa \tau o l)$, who is in charge of human affairs, instruct Christians to love their enemies (Suppl. 11-12). Their God is the Creator, who oversees history and will judge human actions (cf. Aristides, Apol. 15; Theophilus, Ad Autol. 3.15).

What the Apologists argue explicitly, is implicit in Paul's reminder in 1 Thessalonians 1:9-10, that the Thessalonians had turned to God from idols in response to his missionary message. The goal of their conversion is specified in two

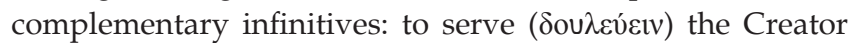
with total allegiance, which implies a moral, sanctified life (see Rm 6:16-23), and to await ( $\alpha v \alpha \mu \varepsilon ́ v \varepsilon v v$ ) his son from heaven, who will deliver them from eschatological judgement. These two implications become pronounced in Paul's ethical instruction in the letter.

\section{Mission}

It has been suggested that the similarity in content between pagan and Christian moral teaching may have been a factor in Christian mission. A.D. Nock thought that the moral standard derived from philosophy or religion made the task of the Christian missionary easier (Nock 1964:1.67). Not many people, however, were able to live up to them, whilst Christianity provided motives for good conduct (fear of God, devotion to Jesus, love of fellow Christians), and claimed great power to satisfy its requirements (Nock 1933:215-216, $218,220)$.

K.-W. Niebuhr is less certain that the similarities aided Christian missions. Whilst he thinks that the confessional inscriptions from western Asia Minor witness to a religiously determined ethics, to a sense of the pervading daily presence of the god, he does not believe that this would have been of positive value for Christian missions. The presence of a god who requires confession of sins and acceptance of punishment in order to avoid further divine sanctions would be onerous rather than comforting. People familiar with a god so involved in their daily life were unlikely to have warmed to the idea of a divine presence that ordered the details of their relationships with each other (Niebuhr 2011:272-274).

Walter Ameling, on the other hand, thinks that Christianity was not morally distinct from those pagans and the Christian moral teaching was therefore the attraction. The similarities include a concern for forgiveness of sins and a proclamation of the greatness of God, which means that there was a fertile ground for missionary preaching (Ameling 2011:246-248).

In what follows we shall see that the content of Paul's ethical instruction had much in common with his environment. But whether that similarity was an attracting element or not is another matter. Such consideration is absent from his description of the Thessalonians' conversion in 1:5-7.

\section{Introducing Paraenesis: 4:1-2}

Paul introduces the last two chapters, usually thought to be the paraenetic section, in 4:1-2. Whilst he was with them,

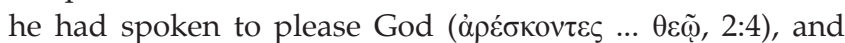

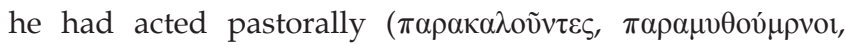
$\mu \alpha \rho \tau$ $\left.{ }^{\prime} \mu \varepsilon v o 1\right)$ to the end that they conduct themselves

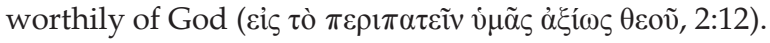

Now, by letter he continues in the same vein. He beseeches

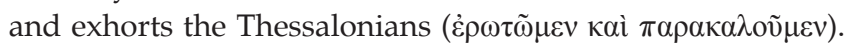
They are to continue in the conduct in which he had instructed them, which they were in fact doing. To follow the teaching they had received from him is to please God ( $\dot{\alpha} \rho \dot{\varepsilon} \sigma \kappa \varepsilon ı v \theta \varepsilon \tilde{\omega})$. Paul uses conventional paraenetic markers to introduce this

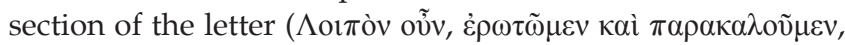

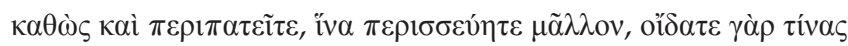

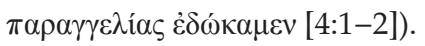

But his readers are addressed as $\dot{\alpha} \delta \varepsilon \lambda \varphi o i$ [brothers], and the

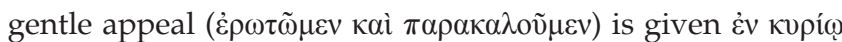

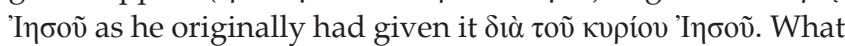
formally and stylistically is a Hellenistic paraenetic letter, is made a Christian pastoral letter, and the ethical instruction is given pastorally.

What is significant for us is that the ethical instruction that follows is a continuation of Paul's pastoral care that he exercised from the beginning of the congregation's existence. They remembered what he had taught them and were 
putting it into practice, and from that perspective, there was no need to provide new content to his teaching. What, then, is the point of what follows? Paul provides clarification about this at the beginning of the first section of paraenesis.

\section{On Sexual Morality: 4:3-8}

The text is enclosed by two brackets, each making a statement about $\dot{\alpha} \gamma 1 \alpha \sigma \mu o ́ s$ [sanctification] (vv. 3, 7), which also appears in connection with the major subject of the section, namely

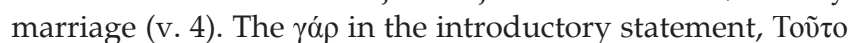

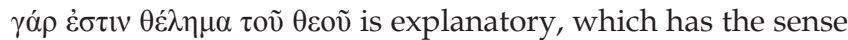
expressed in the paraphrase, 'Well, to be explicit, God's will is this,' which is then identified as sanctification, $\dot{\alpha} \gamma 1 \alpha \sigma \mu \mathrm{os}_{\mathrm{s}}$,

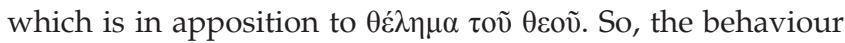
in which the Thessalonians had been instructed, in which they were still engaged and were pleasing God, is their sanctification, which is the real subject of verses $3-8$, and is what Paul stresses.

K.-W. Niebuhr suggested that Jewish and Christian identity was not found in the content of their moral teaching, but in their claim that it was the will of God (Niebuhr 1987:70-72), to which W. Ameling objected that that idea would have meant little to pagans, who would have been astonished by the similarity to the ethics they had been taught by popular philosophy or religion (Ameling 2011:246). They are both correct with respect to 1 Thessalonians $4: 3-8$. The content of the teaching is not unique, and the notion of the will of God, in which the readers had been instructed, was not clear to them, hence the need for Paul to provide the clarification.

A $\gamma 1 \alpha \sigma \mu$ ò here is a noun describing action (cf. 2 Th 2:13), not a condition (ctst. $\dot{\alpha} \gamma 1 \omega \sigma 0 ́ v \eta, 3: 13)$. The action is that of Paul's readers (cf. v. 7 for God's action), which is specified in a series of infinitives marking a progression in thought. The first is

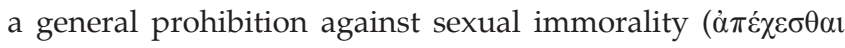

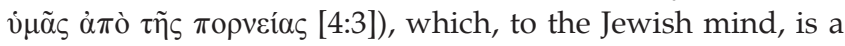
vice characteristic of pagans, and was frequently associated with idolatry (Wisdom 14:13; cf. Rm 1:24, 26). It is natural that Paul would begin in this way in writing to readers who not too long beforehand had turned from idols to serve the living and true God (1:9). He would have had to make the connection between morality and religion very early in his instruction.

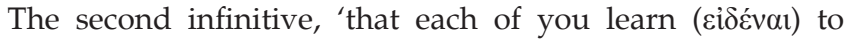

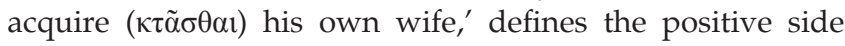
of sanctification. The most likely meaning, I think, is that individuals should enter marriage in holiness and honour

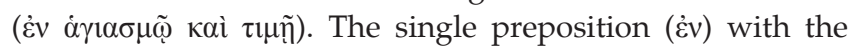
two nouns combines them, but $\dot{\alpha} \gamma \alpha \sigma \mu$ ó ${ }_{\text {, }}$ given the context, predominates. That is what stands out, not that they act in honour.

Musonius Rufus, Paul's contemporary, thought that sexual relations outside marriage were dishonourable (frag. 12), and others thought that one could marry for dishonourable reasons. Even within marriage, sensual pleasure was said to be short, in contrast to honour, kindness and affection (Mus Ruf, frag. 13; Plutarch, The Dialogue on Love 754; cf. Ps.-Arist., Concerning Household Management 3.23-25). ${ }^{7}$ What distinguishes Paul is that the marriage relationship is defined from a religious perspective, as sanctification, which is what would have been new to his Gentile converts.

Paul's positive statement on marriage, as sanctification, is accentuated by a negative antithesis, 'not in lustful passion like the pagans do who do not know God.' Paul's language, $\pi \alpha \dot{\theta}$ os $\dot{\varepsilon} \pi$ ı $\theta$ ouías ('lustful passion' [cf. 4:5]) is derived from his Stoic contemporaries, who defined this emotion as an irrational or intemperate movement of the soul, a craving opposed to reason. One should discipline or train this emotion, according to Musonius, rather than indulge in extramarital sex (frag. 12) or hit on someone else's wife (frag. 7).

Whilst the actual behaviour that Paul inculcates, not to be lustful, is shared with his pagan contemporary, the cause of the behaviour to be rejected is ascribed differently. Paul does not attribute it to a psychological deficiency, a lack of discipline properly exercised by reason, but he instead interprets the condition theologically, as a result of ignorance of God. This is Jewish moral tradition (Wisdom 14:12, 22-27) that Paul also uses in Romans 1:18-32. The thought is clarified by 1 Peter 1:14-16:

As obedient children, do not be conformed to the passions of

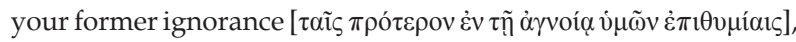
but as he who called you is holy, be holy yourselves in all your conduct; since it is written, 'You shall be holy, for I am holy.'

The sanctified life is a consequence of having turned from idols to serve a living and true God (1:9). Paul had subsequently taught his converts to live lives worthy of God who calls them into his kingdom and glory (2:12). The sanctified life, specified in the way Paul explains it in 4:3-8, is what is implied.

What would be striking to the Thessalonians' neighbours is not the prohibition against sexual immorality, but that the immoral action in view is against a 'brother.' Paul is not here concerned with sexual behaviour vis a vis the larger society but that within the community of ó $\delta \varepsilon \lambda$ poi [brothers], which is the family created by God the Father. Timothy probably informed Paul of a particular circumstance in the congregation that called for his instruction on the subject.

The reason for his demand, Paul says, is that God is an avenger of all these things. The moralists also held that the gods punished the covetous and watched over marriage (Musonius Rufus, frag. 14). Paul's thought is derived from the Old Testament and Jewish tradition. More immediately, Paul's reference is to what he himself had told them and charged them. They had accepted from Paul the expectation of a coming judgement (1:10), and he had charged them, during his ministry with them, to conduct themselves in a Zimmermann 2010). 
manner worthy of God who calls them into his kingdom and glory (2:12). He now relates that call explicitly to this particular moral behaviour: 'For God did not call us to impurity but in sanctification. The person who rejects this charge rejects no human but God, who gives his Holy Spirit to them' (v. 8), and the section ends with the threat that to reject his directions is to reject God who bestows his Holy Spirit.

What is remarkable about this passage on sexual morality, is how little is said specifically about behaviour: do not be be sexually immoral, marry, do not commit adultery. That was hardly new to the morally reflective person. What does stand out is how saturated the passage is with theological warrants for Paul's advice:

- sanctification, which is God's will

- knowledge of God

- God as eschatological judge

- God's call in sanctification

- God's gift of the Holy Spirit.

This makes Paul's directive more than the promotion of marriage as an anodyne against sexual immorality, as it is in 1 Corinthians 7:1-2, 9. Writing to recent converts from paganism, he goes to great lengths to characterize the Christian life as more than obedience to the precepts of a revered teacher. Paul was no ordinary teacher; instead he spoke to the Thessalonians through the Lord Jesus, the will of God, which was that their lives needed to be sanctified. That concept was the great challenge to them.

\section{On brotherly love and self-sufficiency: 4:9-12}

From sexual morality within the church, Paul turns to a new subject, love within the Christian community and the Christians' relationship to outsiders. What was expressed in 3:12 as a prayer, 'May the Lord cause you to increase and abound in love for one another and for all,' is now treated as a moral obligation imposed by God. The style of the instruction is pure paraenesis: you do not need me to write to you, you are taught by God to do what I have to tell you, you are in fact already doing it, just do so more and more, just as I instructed you.

This earliest teaching on Christian social ethics is extraordinarily dense with contemporary social and political terminology: $\Phi 1 \lambda \alpha \delta \varepsilon \lambda \varphi{ }^{\prime} \alpha$, to be ambitious, to be quiet, to mind one's own affairs, one's attitude toward those not of one's own group (the outsiders), and to be self-sufficient. A rapid overview will sketch the context of Paul's instructions and sharpen the point he seems to be making.

Paul begins his instruction in kinship terms, 'Concerning love of the brethren.' $\Phi 1 \lambda \alpha \delta \varepsilon \lambda \varphi$ í $\alpha$, used by pagans for love of blood relations, is used by Paul for love between Christians. The analogous relationship between non-Christians was described by them as $\varphi \imath \lambda i \alpha$, friendship, a virtue of the utmost importance in antiquity (Fitzgerald 1996, 1997). Whilst the virtue was celebrated by everyone, a variety of opinions were held about it. A recognition of some of them affords an idea of the moral discussions which formed the environment within which Paul wrote.

Philosophers differed amongst themselves on how they conceived of the origin of friendship. Some, like the Stoics, thought that we have an innate capacity for friendship, whilst the Epicureans were accused of having a purely utilitarian view, namely, that we develop friendships so that we will have people who will want to meet our future needs. In tension with both was the virtue of self-sufficiency, which everyone aspired to. How could one reconcile self-sufficiency with the endless discussions of how to give and receive gifts? The answer was found in concentrating on the character and motive of the giver rather than the receiver.

By casting the issue as one between brothers, Paul makes it part of the theme of sibling relationship, which has run through the letter up to this point. The Thessalonians had heard Paul speaking God's word to them $(2: 2,4,8,9)$, and they accepted what he said as God's word (2:13). Part of that divine teaching had been that they were to love each other.

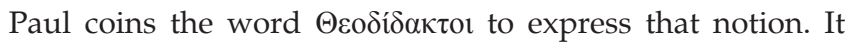
stands in stark contrast to some philosophers' claim that they were 'self-taught' or 'untaught' (Malherbe 2000:244-245). For Paul, the loving relationship between members of the Christian family is not an inborn capacity, and therefore is subject to a consideration of the donor's character or motive, nor does he consider securing a guarantee of reciprocal generosity. It is, simply, a divine mandate to love.

Once more, a generally accepted virtue is made a religious command. That would have stood out for the Thessalonians, both the Christians and their pagan neighbours. So too would have stood out Paul's directive that love be extended to the Christian family, not the larger society. In 3:12, all people are to be recipients of the Thessalonian Christians' love, but here Paul is concerned with a particular issue in the church, which emerges in verse 11.

Paul's exhortation continues with an eye-catching

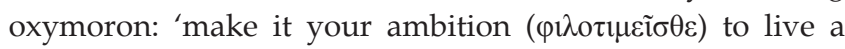

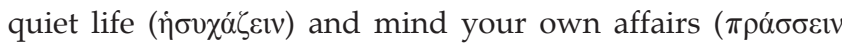

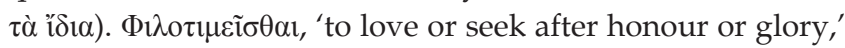
described the effort of the ambitious man who became involved in public affairs. In a society driven by an intense desire for recognition, to refuse to do so, as the Epicureans did, evoked severe criticism. Epicureans withdrew from political and social involvement and organized themselves into conventicles of friends, much to the chagrin of Plutarch, who held that the responsible person should enter public life and contribute to the body politic.

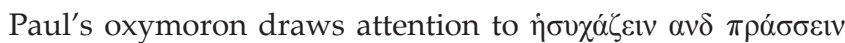
$\tau \grave{\alpha} \iota \delta 1 \alpha$, which describes a kind of quietism quite popular in the first century, not only found amongst Epicureans. It had a venerable history. Plato in the fourth century BC said: 


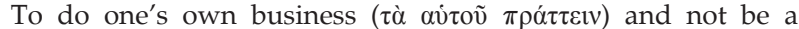

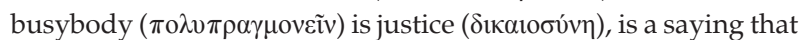
we have heard from many and have often repeated ourselves. (Rep. 4.441DE)

The philosopher lives quietly and tends to his own affairs

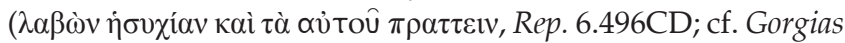
526C), but so also are craftsmen to do. The state is well run when craftsmen work at their trades, each person doing

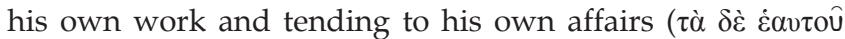

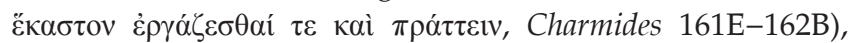
when the cobbler does his work and the carpenter his (Rep. 4.443CD). Such language became widespread by the early Roman Empire (e.g. Dio Cassius, Roman History 60.27; Ps.-Socrates, Epistles 24-26).

Paul explains how they are to love each other in two steps,

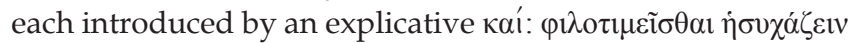

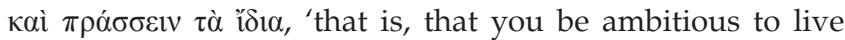
quietly and do your own thing.' That in turn is explained with

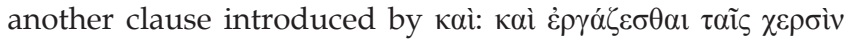
v $\mu \tilde{\omega} v$, 'that is, that you work with your own hands.' When reminding his readers earlier in the letter of his ministry with them, he had referred to his own manual labour as a demonstration of his love for them (2:8-9; cf. 2 Cor 11:11). Paul now asserts that the Thessalonians' love for each other cannot be separated from their work, and he refers to that earlier instruction.

It was difficult for the elite to escape criticism when they withdrew from productive public lives, and it was impossible for the working classes to do so. Lucian excoriates manual labourers who abandoned their trades upon supposedly converting to philosophy (Runaways 14; Double Indictment 6; Philosophies for Sale 11). Idle Christians would have stood out in the crowded quarters where they lived and plied their trade. The elite looked down on manual labour, but thought it appropriate for the lower ranks of society, where the critics of Christians placed them, and where the Thessalonians belonged. Lucian thought of Christians as susceptible to being taken advantage of by unscrupulous new converts like Peregrinus, and his view of them was not unique.

Paul shows a positive attitude toward non-Christians in the letter. He prays that the Lord make the Thessalonians increase and abound in love to each other and to all people (3:12). The Christians are not to retaliate, but to pursue what is good to all people (5:15). Paul may refer to non-Christians as 'outsiders,' but that does not mean that there was no social interaction between Christians and non-Christians. The situation in Thessalonica was probably no different from that in Corinth, where Christians and 'outsiders' had social intercourse with each other even when the Christian brothers were held to a higher standard of morality (1 Cor 5:9-13). Some were still married to pagans, and Paul did not wish such marriages to be dissolved (1 Cor 7:12-16). He was sensitive to Christian etiquette when invited to dinner by a pagan neighbour (1 Cor 10:27-29), and to pagan reaction to a Christian worship service (1 Cor 14:23-25).

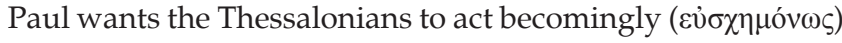
to the outsiders (v. 12). What that means in this context is that they were to be self-sufficient and not sponge of each other, which would likely have met with pagan opprobrium, like that of Lucian. As the pagan discussions of friendship included a consideration of self-sufficiency, so does Paul's treatment of brotherly love. He probably writes on the subject because Timothy had informed him that Paul's recent converts needed instruction on the matter. He had made much of their sibling relationship. It would have been natural if some of them had applied some of the conventions of friendship to brotherly love, one being that friends have all things in common. Whether they did so or not, the behaviour attributed to them in 2 Thessalonians 3:6-15 is congruent with such an understanding. In response, Paul refers to the paradigmatic character of his own practice.

Paul's reminder of his manual labour in 2:9 has the same function and he recalls it in 4:11. Paul worked in order to show his love and to avoid being a burden to anyone. Speaking for God, he taught that working to support oneself was the correct way to show brotherly love. That is also his argument in 4:9-12. What is remarkable; however, especially in light of the immediately preceding verses, is the dearth of theological language and the fullness of social and political terminology.

Why does Paul write in this way? We can infer something from what he says later about how his readers were to admonish each other. Admonition is the harshest speech amongst the many that Paul mentions in the letter. It literally means to instil sense (vov $\theta \varepsilon \tau \varepsilon i v)$ in someone and teach him what should and should not be done. It was associated with frank speech $(\pi \alpha \rho \rho \eta \sigma i \alpha)$, included reproof and rebuke, and was not undertaken lightly. In 5:15, Paul commands the Thessalonians to admonish oi ö $\tau \alpha \kappa \tau o l$, which has traditionally

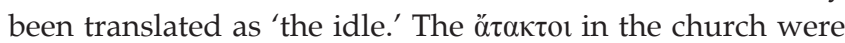
idle, but if Paul simply wanted to identify them by their indolence, he could have used more common words such as

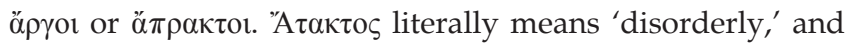
refers to someone who does not submit to accepted norms of behaviour, such as those he had detailed in 4:9-12.

Paul must have heard from Timothy that there were some Thessalonians who did not work, which he describes as $\dot{\alpha} \tau \alpha \xi i \alpha$. Their disorderliness took the form of idleness, which caused a strain in the social fabric. From 2 Thessalonians 3:6-15 it is clear that they disregarded his command and example of working to support himself in order not to burden the Thessalonians. They were not working but were

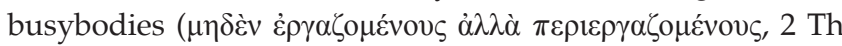
$3: 11$ ), they were acting in direct opposition to the dictates of Plato and the moral philosophers. Paul does not want them to rock the social boat, and to make his point he describes the situation in conventional political terms, confining his peculiarly Christian comments to making his directive a divine teaching on brotherly love. 


\section{Conclusion}

Paul prefaces his paraenesis (ch. 4 and 5) by reminding his readers of how he had brought them to conversion and sought to maintain contact with them (ch. 1-3). The close personal relationship between them was brought about by the powerful message that he spoke, and empowered by God to do so. Paul's, or better, God's gospel, was transparent in his life, and the two could not be separated. Paul's behaviour in their midst, from the very beginning, as the dynamic word worked its way in them, demonstrated the ethical demands of the new religious commitment that they were making.

God created a family for himself through the gospel that Paul preached. Within that family, Paul writes as a brother to his Thessalonian siblings, not as an authoritative father. Paul's ethical instruction was intracommunal yet not without an extracommunal reference. The kinship language they used to describe their relationship to one another, and the love they demonstrated in practical terms to each other would draw the jaundiced eye of their pagan despisers.

Nevertheless, the content of Paul's ethical teaching did not differ very much from the ethical norms of those critics. Paul's converts would already have known what he had taught originally, and by the time he wrote the letter to the Thessalonians, they had the additional advantage of Paul's teaching and example, in accordance with which Paul says they were already living, so that he really had no need to write to them.

So, why does he write anyway? The reason he writes is to explicate the theological rationale for Christian conduct. Before they converted, the Thessalonians would not have related religion and morality together. Paul came on the scene, brought them to conversion, and remained their moral paradigm. But Paul (and Timothy) thought that they still inadequately viewed their moral life as a religious life. Paul sets out to correct this shortcoming. He consistently presents himself as having spoken for God, and in the letter he presents his ethical teaching as part of the divine scheme. But there are differences in the degree to which he plays on the theological themes in dealing with sexual and social ethics.

\section{Acknowledgements}

\section{Competing interest}

The author declares that he has no financial or personal relationship(s) which may have inappropriately influenced him in writing this article.

\section{References}

Ameling, W., 2011, 'Paränese und Ethik in den kleinasiatischen Beichtinscriften', in R.J. Deines \& K.W. Niebuhr (Hrsg.), Neues Testament und hellenistisch-jüdische Altagskultur, pp. 241-249, Mohr Siebeck, Tübingen. (WUNT, 274).

Balch, D., Ferguson, E. \& Meeks, W.A. (eds.), 1990, Greeks, Romans, and Christians: Essays in honor of Abraham J. Malherbe, Fortress, Minneapolis.

Bultmann, R., 1924, 'Das Problem der Ethik bei Paulus', ZNW 23, 123-140.

Deines, R., Herzer, J. \& Niebuhr, K.-W., 2011, Neues Testament und hellenistischjüdische Altagskultur, Mohr Siebeck, Tübingen. (WUNT, 274).

Engberg-Pedersen, T., 2000, Paul and the Stoics, Westminster John Knox, Louisville.

Engberg-Pedersen, T., 2010, Cosmology and the self in the Apostle Paul: The material spirit, Oxford University Press, Oxford. http://dx.doi.org/10.1093/acprof:o so/9780199558568.001.0001

Fitzgerald, J.T. (ed.), 1996, Friendship, flattery, and frankness of speech: Studies on Friendship in the New Testament World, Brill, Leiden. (NovTSup 82).

Fitzgerald, J.T. (ed.), 1997, Greco-Roman perspectives on friendship, Scholars Press, Atlanta. (SBLRBS 24).

Harnack, A., 1908, The mission and expansion of Christianity in the first three Centuries, G.P. Putnam's Sons, New York.

Hock, R.F., 1980, The social context of Paul's ministry: Tentmaking and Apostleship, Fortress, Philadelphia.

Horn, F.W. \& Zimmermann, R. 2009, Jenseits von Indikativ und Imperativ Kontexte und Normen neutestamentlicher Ethik, Mohr Siebeck, Tübingen. (WUNT, 238).

Judge, E., 2010, Jerusalem and Athens, Mohr Siebeck, Tübingen. (WUNT, 265).

Klauck, H.-J., 2003, 'Die kleinasiatischen Beichtinschriften und das Neue Testament', in Religion und Gesellschaft im frühen Christentum, pp. 57-81, Mohr Siebeck, Tübingen. (WUNT, 152).

Lührmann, D., 1990, 'The beginnings of the church at Thessalonica', in D. Balch et al. (ed.), Greeks, Romans, and Christians: Essays in honor of Abraham J. Malherbe, pp. 237-249, Fortress, Minneapolis.

Malherbe, A.J., 1970, 'Gentle as a nurse: The Cynic background to 1 Thess 2', Novum Testamentum 12, 203-217.

Malherbe, A.J., 1987, Paul and the Thessalonians: The Philosophic Tradition of pastoral care, Fortress, Philadelphia.

Malherbe, A.J., 1989, Paul and the popular philosophers, Fortress, Minneapolis.

Malherbe, A.J., 1992, 'Hellenistic Moralists and the New Testament', ANRW 2(26), 3, 267-333.

Malherbe, A.J., 1995, 'God's new family in Thessalonica', in L.M. White \& O.L. Yarbrough (eds.), The social world of the first Christians: Essays in Honor of Wayne A. Meeks, pp. 116-125, Fortress, Minneapolis.

Malherbe, A.J., 1998, 'Conversion to Paul's Gospel', in A.J. Malherbe \& J. Thompson (eds.), The early church in its context: Studies in honor of Everett Ferguson, pp. 231-244, Brill, Leiden. (NovTSup 90).

Malherbe, A.J., 2000, The letters to the Thessalonians, Doubleday, New York. (AB32B).

Malherbe, A.J., 2007, 'The virtus feminarum in 1 Timothy 2:9-15', in M.H. Hamilton, T.H. Olbricht \& J. Peterson (eds.), Renewing Tradition: Studies in Texts and Contexts in Honor of James W. Thompson, pp. 24-44, Pickwick, Eugene, OR.

Niebuhr, K.W., 1987, Gesetz und Paränese: Katechismusartige Weisheitsreihen der jüdischen Literatur, Mohr Siebeck, Tübingen. (WUNT, 2.28).

Niebuhr, K.W., 2011, 'Jüdisches, jesuanisches und paganes Ethos im frühen Christentum', in R. Deines et al., Neues Testament und hellenistisch-jüdische Altagskultur, pp. 251-274, Mohr Siebeck, Tübingen.

Nock, A.D., 1933, Conversion: The old and the new in religion from Alexander the Great to Augustine of Hippo, Clarendon, Oxford.

Nock, A.D., 1964, Early Gentile Christianity and its Hellenistic background, Harper \& Row, New York.

Nock, A.D., 1972, Essays on religion in the ancient world, 2 vols., ed., Z. Stewart, Harvard University Press, Cambridge, MA.

Schnelle, U., 2005, Apostle Paul: His life and theology, Baker Academic, Grand Rapids.

Schrage, W., 1968, The ethics of the New Testament, Fortress Press, Philadelphia.

Starr, J. \& Engberg-Pedersen, S., 2005, Early Christian Paraenesis in Context, De Gruyter, Berlin. (BZNW, 125).

Thompson, J.W., 2011, Moral Formation according to Paul, Baker Academic, Grand Rapids.

Zimmermann, R., 2009, 'The "implicit ethics" of New Testament writings: A draft on a new methodology for analyzing New Testament ethics', Neotestamentica 43, 399-423.

Zimmermann, R., 2010, 'Ehe, Sexualität und Heiligkeit: Aspekte einer Ehe-Ethik im Neuen Testament', in Ehe als Erstfall der Geschlechterdifferenz: Herausforderungen für Frau und Mann in Kulturellen Symbolsystemen, pp. 87-113, Lit Verlag, Berlin. 